\title{
Biogeography of planktonic bacterial communities across the whole Mediterranean Sea
}

\author{
F. Mapelli ${ }^{1}$, M. M. Varela ${ }^{2}$, M. Barbato ${ }^{1}$, R. Alvariño ${ }^{2}$, M. Fusi ${ }^{1}$, M. Álvarez ${ }^{2}$, G. Merlino ${ }^{1}$, D. Daffonchio ${ }^{1}$, and \\ S. Borin ${ }^{1}$ \\ ${ }^{1}$ Department of Food, Environmental and Nutritional Sciences, DeFENS, University of Milan, Via Celoria 2, 20133 Milan, \\ Italy \\ ${ }^{2}$ Instituto Español de Oceanografía, Centro Oceanográfico da Coruña, Paseo Marítimo Alcalde Francisco Vázquez no. 10A, \\ Coruña, Spain
}

Correspondence to: S. Borin (sara.borin@unimi.it)

Received: 4 January 2013 - Published in Ocean Sci. Discuss.: 4 February 2013

Revised: 14 May 2013 - Accepted: 31 May 2013 - Published: 8 July 2013

\begin{abstract}
Bacterial population distribution in the Mediterranean Sea has been mainly studied by considering small geographical areas or specific phylogenetic groups. The present study is a molecular microbiology investigation aimed to identify the environmental factors driving total bacterioplankton community composition of seawater samples collected along a transect covering the whole Mediterranean Sea. We performed automated ribosomal intergenic sequence analysis (ARISA) and microscope evaluation of prokaryotic abundance of seawater sampled across both vertical profiles and longitudinal transects in the whole basin. Prokaryotic abundance decreased with depth at all the stations and presented similar values in epi-, meso- and bathypelagic layers across the whole Mediterranean Sea. However, peculiar bacterial assemblages were selected along a longitudinal transect in the epipelagic layers of the eastern and western sub-basins. Vertical differences of the bacterial communities were observed only when considering the epi- and bathypelagic waters, while the study of the structure of bacterial communities at a finer scale across the water column displayed higher variability at the intermediate layers. Nonetheless, different physico-chemical factors were significantly related to the distribution of bacterial populations, both according to geographic position and down the water column in the whole Mediterranean Sea. These results demonstrated that bacterial assemblages are putatively correlated to different water masses of the complex hydrographical systems of the eastern and western Mediterranean sub-basins.
\end{abstract}

\section{Introduction}

Prokaryotes are key players in sea ecosystems both in terms of biomass and phylogenetic diversity and for their role in biogeochemical cycles. Only recently, due to the development and advancement of molecular tools, have marine scientists carried out studies of the distribution and adaptation of microbial populations to specific environmental conditions in oceans (Agogué et al., 2011; Fuhrman et al., 2008; Galand et al., 2009; Hewson et al., 2006; Lovejoy et al., 2002; Varela et al., 2008a; Yilmaz et al., 2012). Nevertheless, some studies have focused on the ecological structuring of prokaryotes in the Mediterranean Sea, mainly through investigation of the eastern sub-basin (Feingersch et al., 2010; Moesender et al., 2001; De Corte et al., 2009; Yokokawa et al., 2010). The Mediterranean Sea has been proposed as a biodiversity hot spot, hosting about 17000 marine species belonging to the Eukarya domain and a number, at present impossible to estimate, of Bacteria and Archaea species (Coll et al., 2010). The Mediterranean Sea is a semi-enclosed basin divided into two main sub-basins by the Sicilian Channel, the western and eastern Mediterranean Sea. A typical trait of Mediterranean seawater is its oligotrophic nature, exceptionally pronounced in the easternmost area, where the conditions can be defined as ultra-oligotrophic. The low amount of inorganic phosphorous has been reported as a limiting factor of primary productivity in the eastern Mediterranean basin (Thingstad et al., 2005). The lack of thermal confines in the Mediterranean deep waters results in warm bottom 


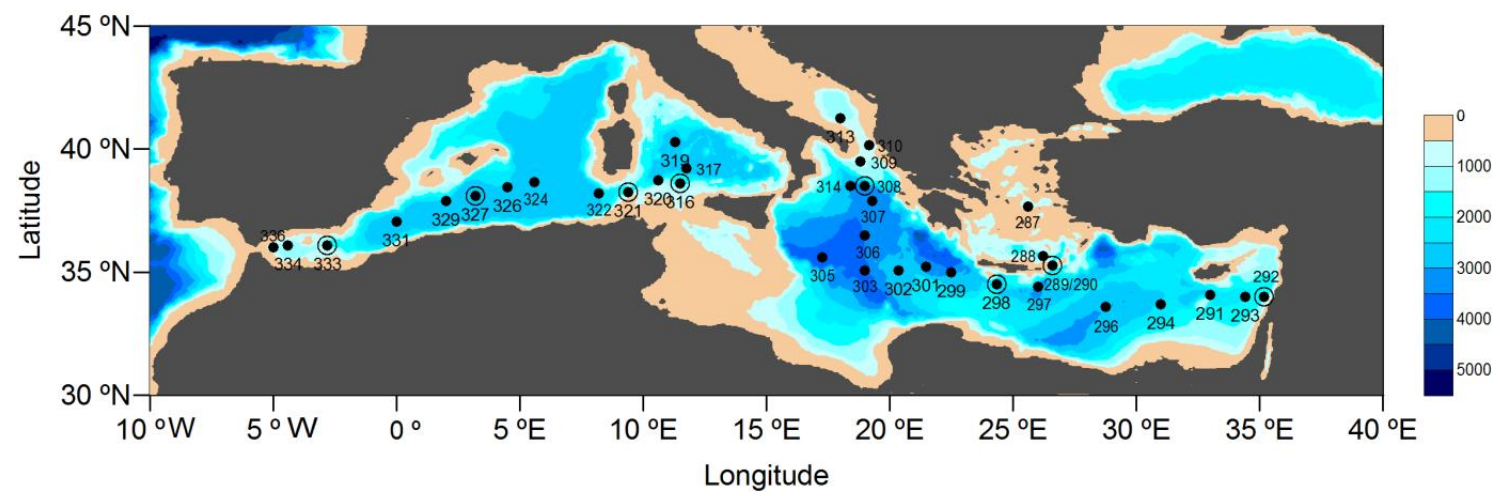

Fig. 1. Location of sampling stations. Map of the study area in the Mediterranean Sea showing the stations where prokaryotic abundance and/or the bacterial community composition was determined (see Table S1 in the Supplement). The stations indicated by encircled dots were subjected to the finer vertical scale sampling to investigate bacterial community structure down the water column. The figure was generated by SURFER 11- Golden Software.

layers and renders this marine ecosystem suitable for the study of partitioning of bacterioplankton throughout the water column, although the effect of pressure must be considered. Recent reports indicate that it is possible to correlate specific microbial community structure to different water masses in the ocean (Agogué et al., 2011; Galand et al., 2009; Varela et al., 2008a, b). However, similar studies performed in the Mediterranean Sea could not draw unequivocal conclusions (Tamburini et al., 2009; Yokokawa et al., 2010), in some cases indicating a depth-related distribution of specific groups of prokaryotes (De Corte et al., 2009; Winter et al., 2009). Indeed, water mass circulation and dynamics are extremely complex in the Mediterranean Sea (Bensi et al., 2013; Hecht et al., 1988; Pinardi et al., 2000, and references therein; Rubino et al., 2007), and a pronounced spatial and temporal variability of water mass composition in the different sub-basins can be related to local geographic peculiarities, such as deep water formation in the Adriatic and the Gulf of Lions, and the water input entering the basin from the Strait of Gibraltar, the Black Sea and the Suez Canal. Most of the microbiological investigations carried out in the Mediterranean Sea focus on a small number of stations, generally located in a narrow area (De Corte et al., 2009; Tamburini et al., 2009; Yokokawa et al., 2010). Taking advantage of the M84/3 cruise, held onboard the R/V Meteor during April 2011, we examined the vertical and longitudinal distribution of bacterial populations at different sampling stations located across the whole Mediterranean Sea, from the Levantine to Alboran basin.

Automated ribosomal intergenic sequence analysis (ARISA) has proven to be a valuable tool for describing the bacterial community structure in marine ecosystems (Borin et al., 2009a, b; Fuhrman et al., 2008; Hewson et al., 2006; Zehr et al., 2009), and it was applied here to depict the bacterial community structure of epi-, mesoand bathypelagic waters. The aims of the present study were (i) to identify distinct or common patterns of bacterial community structure in epipelagic and deep waters sampled at 23 stations along a longitudinal transect in the whole Mediterranean Sea, and (ii) to describe the microbiome composition of seawater collected throughout the water column at eight stations located in the eastern and the western Mediterranean basins.

To the best of our knowledge this is one of the most comprehensive investigations of bacterioplankton distribution realized along a longitudinal transect in the oligotrophic surface and deep Mediterranean seawater.

\section{Materials and methods}

\subsection{Study site, sample collection and oceanographic data}

Sampling was carried out during the cruise M84/3 held on April 2011 on the R/V Meteor. Sampling stations were located in the main sub-basins (eastern and western) of the Mediterranean Sea, across a longitudinal transect of about $3500 \mathrm{~km}$ (Fig. 1). Water samples were collected from epi- $(0-100 \mathrm{~m})$, meso- $(100-1000 \mathrm{~m})$ and bathypelagic $(>1000 \mathrm{~m})$ layers of the water column in order to investigate prokaryotic abundance and bacterial community composition: (i) in epipelagic and deep waters along the whole longitudinal transect, and (ii) at a finer vertical scale in the water column at eight stations to elucidate the vertical profiling of prokaryotic communities in the eastern and western sub-basins. The eight stations were chosen in order to cover the basin-wide variability of the epipelagic water layers (Atlantic Surface Water), the salinity maximum associated with Levantine Intermediate Water and the deep waters in the eastern and western Mediterranean, the Adriatic and the Aegean seas (Table S1 and Fig. S1 in the Supplement). 
Water samples were retrieved at different depths (from $5 \mathrm{~m}$ to a maximum depth of $4190 \mathrm{~m}$ ) of the water column by using Niskin bottles housed on a cable-connected rosette sampler under the control of a CTD (conductivity/temperature/depth) probe (Seabird 19 Plus), providing the measurements of salinity, temperature and pressure. Inorganic nutrient concentration was measured onboard using a segmented flow SkalarSANplus System Instrument (Rahav et al., 2013; Tanhua et al., 2013a). Dissolved oxygen was measured following the Winkler potentiometric method as described by Tanhua et al. (2013a).

\subsection{Abundance of prokaryotes}

Prokaryotic abundance was determined in seawater collected from the Niskin bottles and fixed with sterile formaldehyde ( $4 \%$ final concentration) in the dark. Subsequently, the samples were filtered on $0.22 \mu \mathrm{m}$ pore size black polycarbonate filters (Millipore, USA), frozen and kept at $-20^{\circ} \mathrm{C}$ until analysis. Prokaryotic abundance was evaluated by 4',6-diamidino-2-phenylindole (DAPI) staining (excitation $340 / 360 \mathrm{~nm}$, emission 440/470 nm). Prokaryotic cells positively stained by DAPI were counted with an epifluorescence microscope. For each sample, 30 microscope fields and more than 3000 DAPI-stained cells were counted. From a sub-set of samples analyzed in triplicate, the counting error was estimated to be less than $25.6 \%$ (average $13.8 \%$ ).

\subsection{DNA extraction and ARISA fingerprinting}

A volume of $4-10 \mathrm{~L}$ of water was filtered through sterile GWSP $0.22 \mu \mathrm{m}$ pore size filters (Millipore, USA). Subsequently, $1.8 \mathrm{~mL}$ of lysis buffer (40 mM EDTA, $50 \mathrm{mMTris}$ $\mathrm{HCl}, 0.75 \mathrm{M}$ sucrose) was immediately added to the filters before storing them at $-20{ }^{\circ} \mathrm{C}$ until extraction. DNA extraction from the filters was performed following the protocol described in Borin et al. (2009b) by the addition of lysozyme and sodium dodecyl sulphate (SDS) to lyze the cells. Proteins were removed from the lysis mixture by proteinase $\mathrm{K}$ and chloroform/phenol extraction before DNA precipitation by isopropanol. The pellet was washed with $70 \%$ ethanol and resuspended in sterile TE buffer. ARISA-PCR was conducted on a standard amount of DNA on each sample by using the primer set ITSF, $5^{\prime}$-GTC GTA ACA AGG TAG GCC GTA- ${ }^{\prime}$ and ITSReub, 5'-GCC AAG GCA TCC ACC $3^{\prime}$, as previously described (Cardinale et al., 2004). ARISA fragments were separated using the ABI3730XL genetic analyzer applying the internal standard 1200-LIZ (Macrogen, Korea) or Peak Scanner Software - Applied Biosystems and the internal standard 1500- ROX. The ARISA analyses were performed separately on (i) epi- and bathypelagic samples across the whole longitudinal transect, and (ii) samples from eight stations across a vertical profile covering epi-, mesoand bathypelagic zones of the water column, performed respectively at the University of Milan and Instituto Español de Oceanografía (IEO). The results obtained were analyzed as two different datasets and are discussed separately in the manuscript in Sects. 3.2-3.4, respectively. The output peak matrix was transferred to Microsoft Excel for the following analysis. Peaks showing a height value $<50$ fluorescence units were removed from the output peak matrix before statistical analyses. Each polymorphic ARISA peak was defined as a different operational taxonomic unit (OTU). To account for variability in size associated with standards, ARISA fingerprints were binned $\pm 1 \mathrm{bp}$ from 150 to $300 \mathrm{bp}, \pm 3 \mathrm{bp}$ from 300 to $500 \mathrm{bp}$ and $\pm 10 \mathrm{bp}>500 \mathrm{bp}$.

\subsection{Statistical analysis}

Non-metric multidimensional scaling (nMDS) was carried out to explore similarities between OTUs, based on the resemblance matrix generated using Bray-Curtis similarity on the presence/absence of the OTUs within each sample. Principal component analysis (PCA) was performed on the environmental data matrix (latitude, longitude, pressure, temperature, salinity and oxygen concentration) to visualize the relationship among the samples. The same set of environmental data was used in the distance-based multivariate analysis for a linear model (DistLM; Anderson, 2002) to determine which significant environmental variables explained the observed similarity among the samples. The Akaike information criterion (AIC) was used to select the predictor variables. The contribution of each environmental variable was assessed, firstly using "marginal tests" to assess the statistical significance and percentage contribution of each variable taken alone, and secondly a "sequential test" was employed to evaluate the cumulative effect of the environmental variables explaining biotic similarity. A distance-based redundancy analysis (dbRDA) was used for graphical visualization of the DistLM results. Significant differences in microbial community composition were investigated by permutational analysis of variance (PERMANOVA; Anderson, 2001), considering the sampling area as a fixed and orthogonal factor. Ecological diversity indices were calculated from the matrix of ARISA OTUs. All the statistical tests were performed by PRIMER v. 6.1 (Clarke et al., 2006), PERMANOVA+ for PRIMER routines (Anderson et al., 2008) and PAST software.

\section{Results and discussion}

\subsection{Environmental parameters}

The longitudinal and vertical distribution of the main physical (temperature and salinity) and chemical (inorganic nutrients and dissolved oxygen) variables measured across the Mediterranean Sea during the M84/3 cruise are described by Tanhua and et al. (2013b). The physico-chemical data shown in Table S1 and Fig. S1 (Supplement) provide the parameters 
Table 1. Region name, layer, physical parameters (salinity and temperature) and chemical parameters (phosphate, nitrate and nitrite) of the stations sampled during the M84/3 Meteor cruise. Mean \pm SD are given for the epi-, meso- and bathypelagic waters. Numbers between brackets indicate the number of stations.

\begin{tabular}{|c|c|c|c|c|c|c|c|}
\hline Region & $\begin{array}{l}\text { Layer } \\
(\mathrm{m})\end{array}$ & Salinity & $\begin{array}{c}\text { Temperature } \\
\left({ }^{\circ} \mathrm{C}\right)\end{array}$ & $\begin{array}{c}\text { Dissolved } \\
\text { Oxygen } \\
\left(\mu \mathrm{mol} \mathrm{L}^{-1}\right)\end{array}$ & $\left.\begin{array}{c}\mathrm{PO}_{4} \\
(\mu \mathrm{mol} \mathrm{L} \\
-1\end{array}\right)$ & $\begin{array}{c}\mathrm{NO}_{3} \\
\left(\mu \mathrm{mol} \mathrm{L}^{-1}\right)\end{array}$ & $\begin{array}{c}\mathrm{NO}_{2} \\
\left(\mu \mathrm{mol} \mathrm{L}^{-1}\right)\end{array}$ \\
\hline \multirow[t]{3}{*}{ Eastern } & $<100$ & $\begin{array}{c}38.80 \pm 0.29 \\
(26)\end{array}$ & $\begin{array}{c}16.58 \pm 0.99 \\
(26)\end{array}$ & $\begin{array}{c}220.46 \pm 1.25 \\
(26)\end{array}$ & $\begin{array}{c}0.01 \pm 0.002 \\
(15)\end{array}$ & $\begin{array}{c}0.18 \pm 0.04 \\
(25)\end{array}$ & $\begin{array}{c}0.02 \pm 0.01 \\
(20)\end{array}$ \\
\hline & $100-1000$ & $\begin{array}{c}38.93 \pm 0.03 \\
(28)\end{array}$ & $\begin{array}{c}14.93 \pm 0.13 \\
(28)\end{array}$ & $\begin{array}{c}189.48 \pm 1.97 \\
(25)\end{array}$ & $\begin{array}{c}0.10 \pm 0.007 \\
(25)\end{array}$ & $\begin{array}{c}3.27 \pm 0.18 \\
(25)\end{array}$ & $\begin{array}{c}0.02 \pm 0.005 \\
(22)\end{array}$ \\
\hline & $>1000$ & $\begin{array}{c}38.76 \pm 0.01 \\
(23)\end{array}$ & $\begin{array}{c}13.89 \pm 0.04 \\
(23)\end{array}$ & $\begin{array}{c}175.02 \pm 1.24 \\
(23)\end{array}$ & $\begin{array}{c}0.18 \pm 0.008 \\
(21)\end{array}$ & $\begin{array}{c}4.69 \pm 0.08 \\
(21)\end{array}$ & $\begin{array}{c}0.006 \pm 0.001 \\
(15)\end{array}$ \\
\hline \multirow[t]{3}{*}{ Western } & $<100$ & $\begin{array}{c}37.15 \pm 0.12 \\
\text { (22) }\end{array}$ & $\begin{array}{c}15.77 \pm 0.14 \\
(22)\end{array}$ & $\begin{array}{c}218.77 \pm 1.90 \\
(22)\end{array}$ & $\begin{array}{c}0.08 \pm 0.01 \\
(21)\end{array}$ & $\begin{array}{c}1.79 \pm 0.37 \\
(22)\end{array}$ & $\begin{array}{c}0.04 \pm 0.006 \\
(22)\end{array}$ \\
\hline & $100-1000$ & $\begin{array}{c}38.10 \pm 0.17 \\
\text { (26) }\end{array}$ & $\begin{array}{c}13.42 \pm 0.07 \\
(26)\end{array}$ & $\begin{array}{c}172.25 \pm 1.58 \\
(26)\end{array}$ & $\begin{array}{c}0.40 \pm 0.03 \\
\text { (19) }\end{array}$ & $\begin{array}{c}8.02 \pm 0.45 \\
(22)\end{array}$ & $\begin{array}{c}0.01 \pm 0.001 \\
(21)\end{array}$ \\
\hline & $>1000$ & $\begin{array}{c}38.36 \pm 0.12 \\
(20)\end{array}$ & $\begin{array}{c}13.05 \pm 0.20 \\
(20)\end{array}$ & $\begin{array}{c}174.94 \pm 0.88 \\
\text { (19) }\end{array}$ & $\begin{array}{c}0.41 \pm 0.03 \\
(17)\end{array}$ & $\begin{array}{c}8.57 \pm 0.55 \\
(17)\end{array}$ & $\begin{array}{c}0.008 \pm 0.003 \\
\text { (13) }\end{array}$ \\
\hline
\end{tabular}

for the characterization of the samples specifically investigated here by microbiological analyses.

Briefly, epipelagic samples were characterized by a high temperature $\left(>16^{\circ} \mathrm{C}\right)$ and salinity $(>36)$, both increasing eastwards due to the salinification of surface Atlantic water as it travels eastwards in the Mediterranean Sea (Table 1). Both nitrate and phosphate were depleted in the epipelagic layer. The physical and chemical values measured in each sample are reported in detail in Table S1 (Supplement). The vertical distribution of salinity basin-wide and the location of the samples collected for microbiological analyses are indicated in Fig. S1 (Supplement). Bottom samples in the western basin presented homogenous temperature and salinity (Table 1 and Fig. S1 in the Supplement), lower than in the eastern basin. Within the bottom samples, those collected from the Aegean Sea showed the highest temperature and salinity values, while the higher nutrient values were recorded in the western basin samples.

\subsection{Prokaryotic abundance decrease throughout the water column of eastern and western Mediterranean basins}

Prokaryotic abundance was estimated at different stations distributed along the two sub-basins (western and eastern) from the epi-, meso- and bathypelagic waters of the Mediterranean Sea (Fig. 2). Prokaryotic abundance ranged between $1.94 \times 10^{8}$ and $8.15 \times 10^{8}$ cell L $^{-1}$ $\left(3.24 \times 10^{8} \pm 1.40 \times 10^{8}\right.$, mean $\left.\pm \mathrm{SE}\right)$ in the epipelagic layer up to $100 \mathrm{~m}$ depth and decreased exponentially with depth to $4.82 \times 10^{7}-3.65 \times 10^{8}$ cell $\mathrm{L}^{-1}\left(9.81 \times 10^{7} \pm 6.60 \times 10^{7}\right.$, mean $\pm \mathrm{SE})$ in the mesopelagic layers and to $2.88 \times 10^{6}$ $1 \times 10^{8}$ cell L ${ }^{-1}\left(4.55 \times 10^{7} \pm 2.50 \times 10^{7}\right.$, mean $\left.\pm \mathrm{SE}\right)$ in the bathypelagic waters. Total microbial abundances reported in this study are in agreement with previously published data for both epipelagic and deeper layers of the water column in different oceanic regions, including the North Atlantic (Varela et al., 2008a; Arístegui et al., 2009), eastern (Borin et al., 2009b; Yokokawa et al., 2010) and western Mediterranean Sea (Luna et al., 2012) and the whole Mediterranean Sea (Zaccone et al., 2012).

The PERMANOVA analysis indicated that prokaryote abundance in the epi-, meso- and bathypelagic zones was significantly different $(p=0.0001)$. Conversely, the comparison of the prokaryotic abundance obtained along the water column between the eastern and western basins of the Mediterranean Sea revealed no significant differences in the epi- $(p=0.3215)$, meso- $(p=0.0628)$ and bathypelagic ( $p=0.4274)$ layers of the two sub-basins. The statistical approach adopted in this study showed that differences in the prokaryotic abundance values are ascribable to a depthrelated decline and excluded any correlation between total cell abundance and specific water mass conditions characterizing the different sub-basins of the Mediterranean Sea.

\subsection{Epi- and bathypelagic water layers host significantly different bacterial communities}

ARISA fingerprinting was applied to detect spatial patterns in the structure of bacterial communities, aiming to identify the correlation between structure and the environmental conditions that characterize the epi- and bathypelagic waters of the Mediterranean Sea. The use of molecular methods based on the PCR amplification of regions of the ribosomal operon is particularly suitable to depict the bacterial community composition in marine oligotrophic ecosystems (Brown et al., 2005; Moeseneder et al., 2001), since bacteria growing 


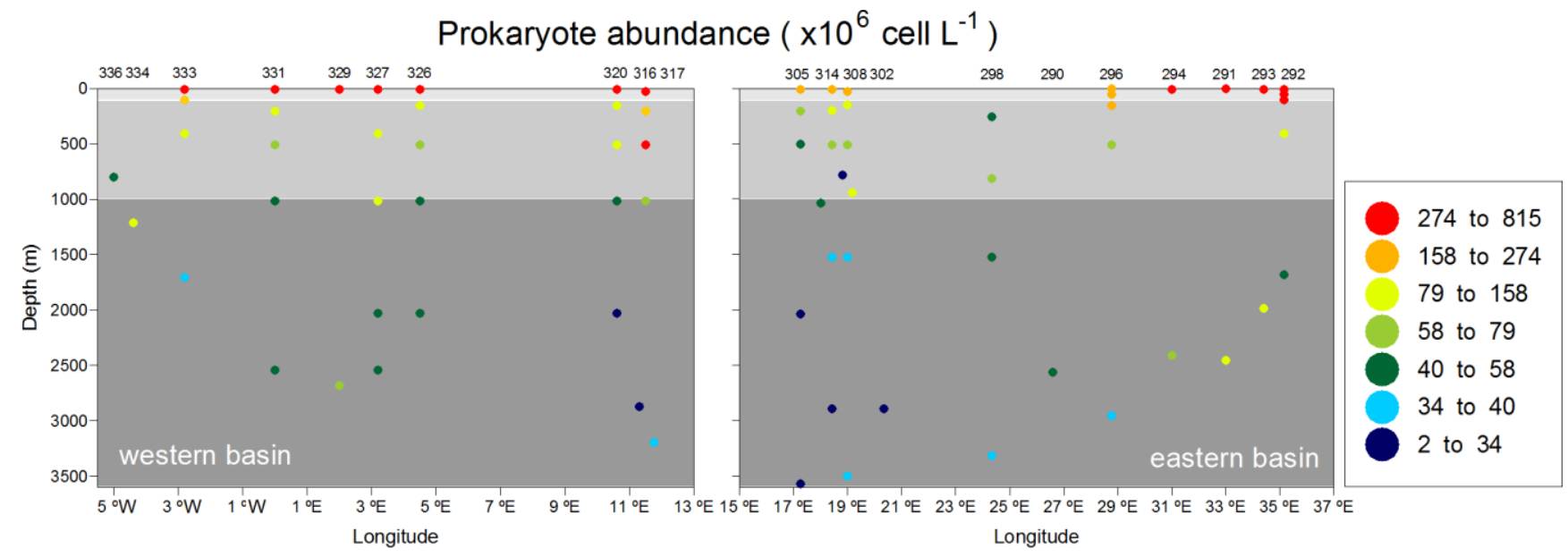

Fig. 2. Prokaryotic abundance across the water column in the eastern and western Mediterranean Sea. Prokaryotic abundance in each of the three water layers (epi-: $\leq 100 \mathrm{~m}$; meso-: 100-1000 m; and bathypelagic: $>1000 \mathrm{~m}$ ) in the eastern and western basin of the Mediterranean Sea during the Meteor cruise. Station name labels are reported only for those stations where prokaryotic abundance was evaluated at two or more depths. The figure was generated by SURFER 11- Golden Software.

in nutrient-poor water generally have single or few identical operon copies (Brown et al., 2005; Fegatella et al., 1998).

The ARISA profiles of the bacterial communities inhabiting the epi- and bathypelagic waters in the eastern and western Mediterranean Sea showed 194 polymorphic peaks in total, ranging between 157 and $1600 \mathrm{bp}$, considered as different bacterial taxa (OTUs). None of the detected OTUs were ubiquitously present in the epi- and bathypelagic layers of the analyzed stations, while $18 \%$ of the OTUs were unique. The ARISA profiles of the epipelagic layers comprised 3268 OTUs $(56.1 \pm 8.9$, mean \pm SE) and displayed Shannon diversity index values ranging between 2.91 and 3.73 (Table S2). However, the ARISA patterns in the bathypelagic layers showed slightly lower numbers of taxa $(45 \pm 13.7$, mean \pm SE) and lower taxonomic diversity (Shannon index values: 1.29-3.67) (Table S2). Of the total OTUs retrieved, 134 out of $194(69 \%)$ were present in the deep layers, whereas only 3 OTUs $(2 \%)$ were shared among all the stations and 31 OTUs (23\%) were singletons. NMDS analysis was applied on the ARISA fingerprints, showing a clear separation between bacterial communities inhabiting the epiand bathypelagic layers (Fig. 3a). The NMDS analysis, characterized by a low stress value, and PERMANOVA test indicated that the bacterial communities in seawater samples collected from the epi- and bathypelagic layers were significantly different $(p=0.0001)$, indicating the occurrence of strong selecting forces that differentiate these water column layers (Fig. 3a).

A PCA was applied to the available environmental data (Table 1) to illustrate the distribution of the samples according to their physico-chemical and geographical parameters (Fig. 3b). Both the epi- and bathypelagic samples were divided according to the longitude and latitude values, whereas the pressure, representing a proxy for depth, mainly determined the segregation of epipelagic and deep samples. A DistLM was applied, with the aim to identify the environmental variables shaping the bacterial community composition in epipelagic and deep waters across a wide transect (about $3500 \mathrm{~km}$ ) in the Mediterranean Sea. The DistLM analysis identified that $68.37 \%$ of total variation was related to five significant environmental variables (Table 2), responsible for the observed spatial distribution of bacterial communities in epi- and bathypelagic zones. The DistLM analysis indicated that longitude $(p=0.04)$, pressure $(p=0.0001)$, salinity $(p=0.0001)$, temperature $(p=0.0001)$ and oxygen concentration $(p=0.004)$ were significant variables, while the latitude was not significantly related $(p=0.36)$ to the variation in bacterial community composition. The two axes of the dbRDA displayed $56.39 \%$ of the total variation (Fig. 3c) overlapping with the bacterial population distribution detected in the epi- and bathypelagic layers with the environmental variables, represented as vectors. Epi- and bathypelagic samples clustered separately according to pressure, temperature and oxygen values, which represent the primary factors driving bacteria partitioning in such different zones of the water column. Microbial zonation according to depth has been previously reported both in the Mediterranean Sea and in the oceans by applying molecular fingerprinting (De Corte et al., 2009; Moeseneder et al., 2001), 16S rRNA pyrotag sequencing (Agogué et al., 2011) and metagenomics (DeLong et al., 2006). In the Mediterranean Sea, the water temperature of the deep layer is only slightly lower than that measured in the epipelagic waters (see Table 1 in this study). Still, the differences in the microbial community structure in the epi- and bathypelagic biomes in the Mediterranean Sea can be ascribed to factors of remarkable influence including 

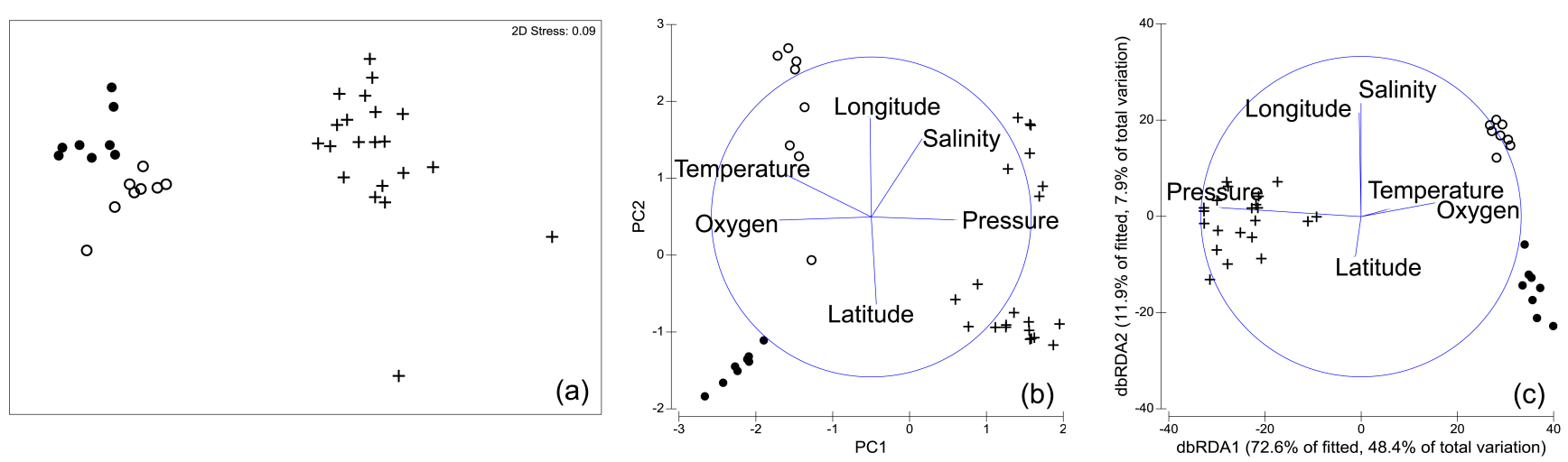

Fig. 3. Distribution of the bacterial communities in the epi- and bathypelagic waters according to biotic and environmental data. (a) Nonmetric multidimensional scaling (NMDS) results based on qualitative ARISA fingerprinting showing a sharp clustering of epi- (open and filled circles corresponding respectively to eastern and western epipelagic samples) and bathypelagic (crosses) seawater samples. (b) Principal component analysis performed on the environmental data reported in Table S1 (Supplement). (c) dbRDA ordinations of the presence/absence of the ARISA dataset overlaid with the partial correlations of the tested environmental variables explaining the clustering of epi- (open and filled circles) and bathypelagic (crosses) seawater samples.

Table 2. Results of distance-based multivariate linear model (DistLM) for bacterial community composition in epipelagic and deep water layers, showing the $\%$ variation explained by individual axes. The first two columns relate to the percentage explained out of the fitted model (individuated with the DistLM analysis). The second two columns relate to the percentage explained out of the total variation in the resemblance matrix used to build up the DistLM model.

\begin{tabular}{lcccc}
\hline Axis & \multicolumn{2}{c}{$\begin{array}{c}\text { Explained variation } \\
\text { (fitted model) }\end{array}$} & \multicolumn{2}{c}{$\begin{array}{c}\text { Explained variation } \\
\text { (total variation) }\end{array}$} \\
\cline { 2 - 5 } & Individual & Cumulative & Individual & Cumulative \\
\hline dbRDA1 & 71.44 & 71.44 & 48.85 & 48.85 \\
dbRDA2 & 11.03 & 82.47 & 7.54 & 56.39 \\
dbRDA3 & 9.29 & 91.76 & 6.35 & 62.74 \\
dbRDA4 & 4.65 & 96.41 & 3.18 & 65.92 \\
dbRDA5 & 2.54 & 98.95 & 1.74 & 67.65 \\
dbRDA6 & 1.05 & 100.00 & 0.72 & 68.37 \\
\hline
\end{tabular}

the hydrostatic pressure effect (Tamburini et al., 2009), selection for piezophilic populations in deep water, light penetration and nutrient profiles. Our study confirms, for the first time on a transect covering the whole Mediterranean Sea, the bacterioplankton communities pattern previously reported at single stations and/or shorter transects in different oceanographic regions around the world.

\subsection{Epipelagic bacterial community composition is patterned according to longitude}

The occurrence of a distribution pattern of planktonic bacterial populations within the epipelagic seawater was gathered from the dbRDA analyses performed on the ARISA profiles of epipelagic and deep waters (Fig. 3c). To investigate in detail the existence of different bacterial assem- blages in the epipelagic water sampled across the Mediterranean Sea transect during the M84/3 cruise, the ARISA profiles of epipelagic samples were analyzed separately, adopting the same approach described above for the whole ARISA dataset. ARISA fingerprinting detected 140 OTUs in epipelagic samples, including 13 ubiquitous OTUs (9\%) and 26 OTUs $(18.5 \%)$ present as singletons. NMDS analysis demonstrated the separation of planktonic bacterial communities inhabiting epipelagic waters in two distinct clusters of samples (Fig. 4a), corresponding to the stations located in the eastern and western Mediterranean Sea. The results of NMDS analysis (stress value $=0.07$ ) were strengthened by PERMANOVA test, showing that the bacterial community structure in the eastern and western sub-basins of the Mediterranean Sea was significantly different $(p=0.0001)$. PCA of the epipelagic samples according to the environmental variables showed a less clear separation among the epipelagic seawaters (Fig. 4b); nonetheless, the DistLM analysis indicated that four significant explaining variables accounted for up to $76.12 \%$ of the total variation detected in the bacterial community composition (Table 3 ). Longitude $(p=0.0001)$, latitude $(p=0.0017)$, salinity $(p=0.0021)$ and oxygen concentration ( $p=0.047)$ were identified as significant variables, while temperature $(p=0.068)$ was not significantly related to the observed biodiversity pattern. The low importance of temperature in determining the distribution of bacterial epipelagic populations was expected, considering that the recorded temperature values were within a narrow range $\left(14.83-18.19^{\circ} \mathrm{C}\right.$ at approximately $5 \mathrm{~m}$ depth) across the epipelagic waters of the eastern and western Mediterranean Sea (Table 1 and Table S1 in the Supplement). The two axes of the dbRDA displayed $58.3 \%$ of the total variation of bacterial distribution (Fig. 4c), indicating that 

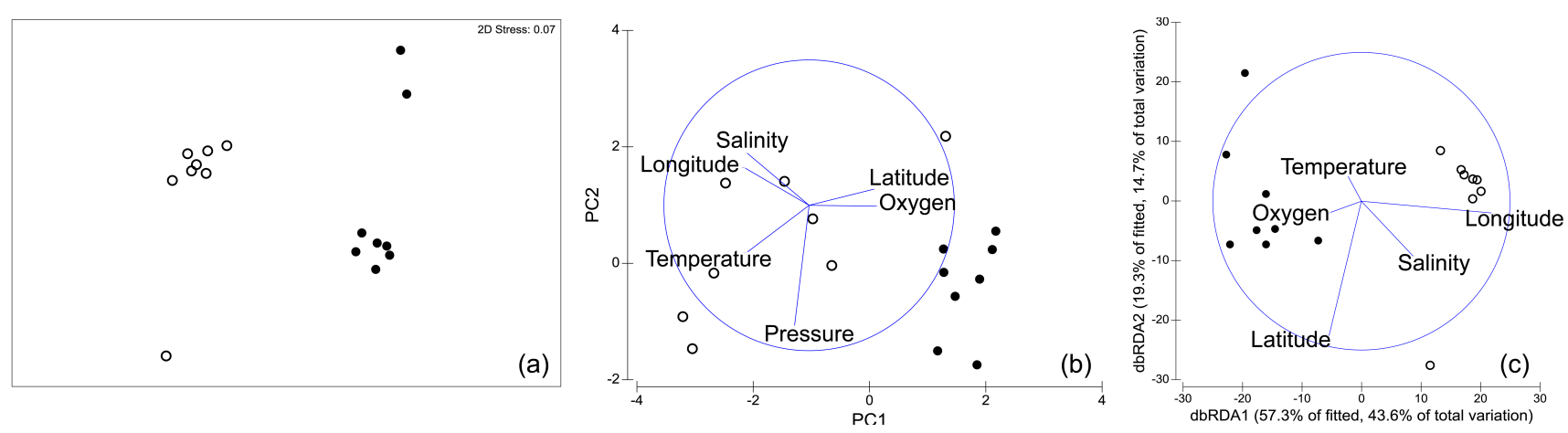

Fig. 4. Distribution of the bacterial communities in the Mediterranean Sea epipelagic waters according to biotic and environmental data. (a) Non-metric multidimensional scaling (NMDS) results based on qualitative ARISA fingerprinting illustrating a clear clustering of eastern (open circles) and western (filled circles) Mediterranean Sea epipelagic water. (b) Principal component analysis performed on the environmental data reported in Table S1 (Supplement). (c) dbRDA ordinations of the presence/absence of the ARISA dataset overlaid with the partial correlations of the tested environmental variables explaining the clustering of eastern (open circles) and western (filled circles) Mediterranean Sea epipelagic water.

Table 3. Results of distance-based multivariate linear model (DistLM) for bacterial community composition in epipelagic waters showing the $\%$ variation explained by individual axes. The first two columns relate to the percentage explained out of the fitted model (individuated with the DistLM analysis). The second two columns relate to the percentage explained out of the total variation in the resemblance matrix used to build up the DistLM model.

\begin{tabular}{lcccc}
\hline Axis & \multicolumn{2}{c}{$\begin{array}{c}\text { Explained variation } \\
\text { (fitted model) }\end{array}$} & \multicolumn{2}{c}{$\begin{array}{c}\text { Explained variation } \\
\text { (total variation) }\end{array}$} \\
\cline { 2 - 5 } & Individual & Cumulative & Individual & Cumulative \\
\hline dbRDA1 & 57.33 & 57.33 & 43.65 & 43.65 \\
dbRDA2 & 19.25 & 76.59 & 14.65 & 58.30 \\
dbRDA3 & 13.44 & 90.03 & 10.23 & 68.53 \\
dbRDA4 & 6.54 & 96.57 & 4.98 & 73.51 \\
dbRDA5 & 3.43 & 100.00 & 2.61 & 76.12 \\
\hline
\end{tabular}

bacterial zonation in epipelagic samples is unambiguously related to longitude, as already inferred from NMDS.

The existence of biogeography patterns in the composition of bacterioplankton communities in epipelagic seawaters was recently demonstrated in the Mediterranean Sea for specific bacterial taxa. The abundance of aerobic anoxygenic phototrophs was shown to be inversely linked to the nutrient concentrations in epipelagic waters of the Mediterranean Sea along a transect covering the whole eastern and part of the western Mediterranean basin (Lamy et al., 2011). Similarly, two diversity studies on Cyanobacteria showed that the Synechococcus (Mella-Flores et al., 2011) and Prochlorohococcus (Mella-Flores et al., 2011) clades were differently distributed in the epipelagic layers of the eastern and western Mediterranean Sea, questioning the possible influence of water inputs from the Suez Canal (Feingersch et al., 2010). About 600 exogenous species belonging to the Plantae and Animalia kingdoms have been introduced into the Mediter- ranean Sea, mainly from the Suez Canal (Coll et al., 2010, and references therein). This is a partial estimation since unicellular organisms are not included in the number of allochthonous species constituting the core of a novel biodiversity imported into the Mediterranean basin. Exogenous species are spatially distributed along the Mediterranean Sea coasts, displaying a higher abundance in correspondence with the Levantine basin (Coll et al., 2010). Possibly, a similar distribution model is followed by planktonic microorganisms, which would diversely impact the epipelagic water of the eastern and western Mediterranean Sea, thus corroborating the results of the present study. Epipelagic seawater samples were collected by Rahav et al. (2013) during the M84/3 cruise, in parallel with the samples analyzed in the present study, and the role of diazotrophy on total primary productivity was estimated. The lowest $\mathrm{N}_{2}$ fixation values were measured in the Levantine basin, while the highest $\mathrm{N}_{2}$ fixation rate was observed at the Gibraltar Strait, corresponding to an east-west trend of increased contribution of $\mathrm{N}_{2}$ fixation to primary productivity, as shown for chlorophyll concentration (Rahav et al., 2013). $\mathrm{N}_{2}$ fixing measurements allowed the inference of the main role of autotrophic and heterotrophic $\mathrm{N}_{2}$ fixing bacteria, respectively, in the eastern and western basins (Rahav et al., 2013), an aspect that might affect the total bacterial community structure in epipelagic seawater. Indeed, the correlation between picophytoplankton and specific groups of bacteria, namely aerobic anoxygenic phototrophic bacteria, was reported in the Mediterranean Sea (Lamy et al., 2011), while bacterioplankton and phytoplankton abundance in the Arctic Ocean showed a similar trend ( $\mathrm{Li}$ et al., 2009). The influence of latitude on the microbiome inhabiting surface waters has already been reported by Fuhrman et al. (2008), who investigated the microbial community assemblages by ARISA fingerprinting in 57 different locations around the world. Salinity values were higher in the eastern 
Mediterranean epipelagic water analyzed in this study compared to those collected in the western basin (Table 1, Fig. S1 in the Supplement). Salinity, together with temperature and oxygen content, is a signature of specific water masses. Its different value in the two sub-basins of the Mediterranean Sea typically mirrors the influence of distinct water masses in the epipelagic layers of the Mediterranean basin due to, for example, the intrusion of cold and less-saline seawater from the Gibraltar Strait into the Alboran Sea and the intense evaporation phenomena in the Levantine basin. The detection of a significant relationship between salinity and oxygen content values and planktonic bacterial assemblages in epipelagic waters collected from the eastern and westernmost areas of the Mediterranean Sea (Fig. 1) suggests that specific water masses in the epipelagic seawater layers influence the impact of certain bacterial taxa in the total planktonic community structure. These data support the concept that specific water masses host a peculiar microbial community, as demonstrated in the North Atlantic (Varela et al., 2008a, b) and the high Arctic (Galand et al., 2009; Hamilton et al., 2008). Moreover, future measurements on quantity and quality of dissolved organic matter might enhance the insight required to explain the variables that determine bacterioplankton composition along the eastern and western Mediterranean Sea.

\subsection{Bacterial populations are stratified across the water column according to environmental variables}

The vertical bacterioplankton community composition at eight stations was assessed by ARISA fingerprinting, showing the occurrence of a vertical profile across the water column (Fig. 5). As illustrated by NMDS analysis (Fig. 5a), the pattern of bacterial community composition was less distinct than previously observed, taking into account only the epipelagic and bottom waters (Fig. 3a); nevertheless, epipelagic samples clustered differently to those from meso- and bathypelagic depths. The structure of bacterial communities of the upper meso- and bathypelagic layers was distinguishable, while the samples collected at the lower mesopelagic depths presented a higher variability (Fig. 5a). A certain degree of variability of sample distribution was detected within the categories, also according to spatial and physico-chemical parameters (Fig. 5b). In spite of the reported unevenness, DistLM analysis showed that four significant variables, longitude $(p=0.0166)$, pressure $(p=0.0014)$, salinity $(p=0.024)$ and temperature ( $p=0.0007)$, explained only $32.79 \%$ of the total variation of the bacterial community composition along the investigated vertical profile (Table 4). dbRDA displayed $24.20 \%$ of the total variation (Fig. 5c), showing that bacterioplankton communities are shaped by longitude, pressure, salinity and temperature.

The investigation of structure of bacterial communities along the depth gradient by ARISA fingerprinting and
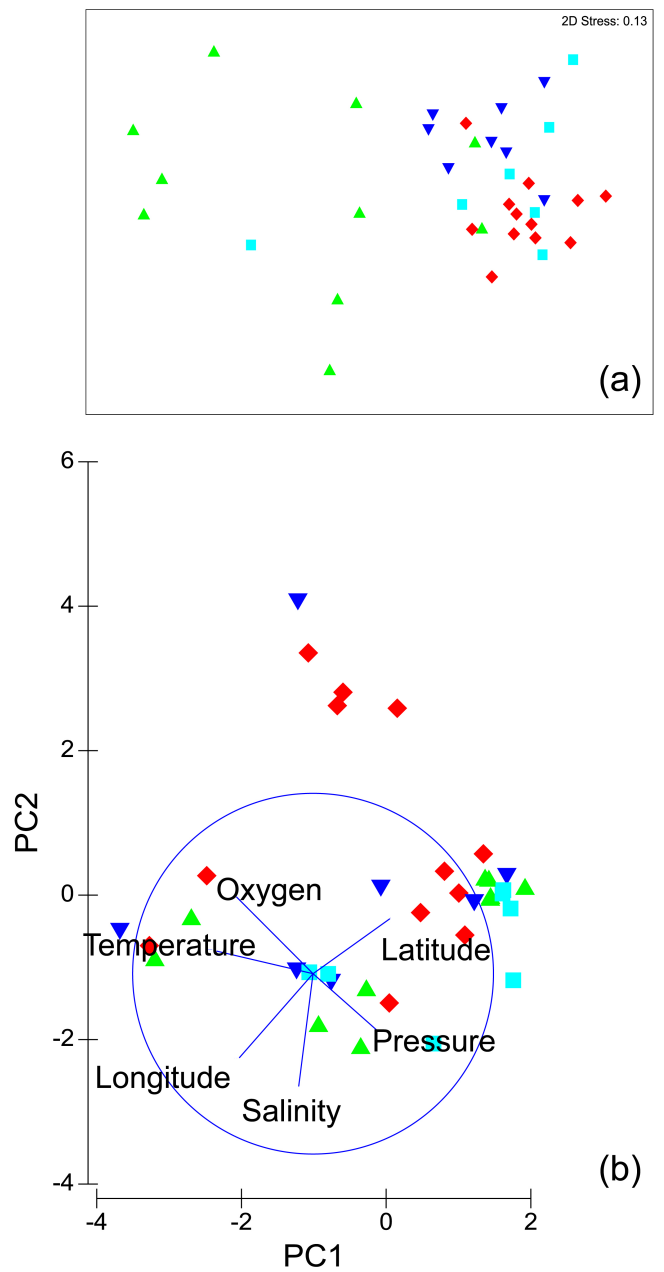

(b)

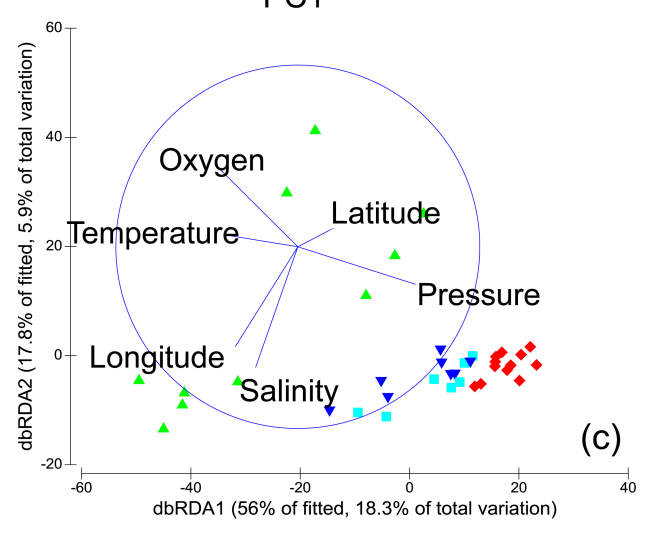

Fig. 5. Distribution of the bacterial communities throughout the water column according to biotic and environmental data. (a) Nonmetric multidimensional scaling (NMDS) results based on qualitative ARISA fingerprinting of the samples across the water column, showing the distribution of epipelagic (green triangles), upper mesopelagic (blue triangles), lower mesopelagic (light blue squares) and bathypelagic (red diamonds) samples. (b) Principal component analysis performed on the environmental data reported in Table S1 (Supplement). (c) dbRDA ordinations of the presence/absence of the ARISA dataset overlaid with the partial correlations of the tested environmental variables. 
Table 4. Results of distance-based multivariate linear model (DistLM) for bacterial community composition in epi-, meso- and bathypelagic seawater layers showing the \% variation explained by individual axes. The first two columns relate to the percentage explained out of the fitted model (individuated with the DistLM analysis). The second two columns relate to the percentage explained out of the total variation in the resemblance matrix used to build up the DistLM model.

\begin{tabular}{lcccc}
\hline Axis & \multicolumn{2}{c}{$\begin{array}{c}\text { Explained variation } \\
\text { (fitted model) }\end{array}$} & \multicolumn{2}{c}{$\begin{array}{c}\text { Explained variation } \\
\text { (total variation) }\end{array}$} \\
\cline { 2 - 5 } & Individual & Cumulative & Individual & Cumulative \\
\hline dbRDA1 & 55.96 & 55.96 & 18.35 & 18.35 \\
dbRDA2 & 17.84 & 73.81 & 5.85 & 24.20 \\
dbRDA3 & 11.58 & 85.39 & 3.8 & 28.00 \\
dbRDA4 & 7.87 & 93.27 & 2.58 & 30.58 \\
dbRDA5 & 4.55 & 97.82 & 1.49 & 32.07 \\
dbRDA6 & 2.18 & 100.00 & 0.72 & 32.79 \\
\hline
\end{tabular}

NMDS analysis (stress value: 0.13) was consistent with the results of the PERMANOVA statistical test. The bacterial species composition in the epipelagic samples was significantly divergent from those collected in the upper $(p=0.0085)$ and lower $(p=0.033)$ meso- and bathypelagic layers $(p=0.0005)$. The upper meso- and bathypelagic strata were also different $(p=0.0017)$. As inferable from NMDS and DistLM analyses, where the distribution of lower mesopelagic samples partially overlapped with the upper mesopelagic and bathypelagic depths, PERMANOVA test showed that bacterial community structure of the lower mesopelagic samples was not significantly different from upper mesopelagic $(p=0.1553)$ and bathypelagic $(p=0.1296)$ bacterial assemblages.

Several recent studies provided hints of a correlation between prokaryotic community composition and water masses, defined as "bio-oceanographic islands" (Agogué et al., 2011; Galand et al., 2009), which carry their own specific microbiome. Fingerprinting methods applied to seawater collected along a north-south transect in the Aegean Sea demonstrated that both free-living and attached bacterial communities clustered according to the region and depth of sampling, highlighting the existence of horizontal and vertical profiling of bacteria in the Aegean Sea (Moesender et al., 2001). The samples analyzed in the present study were collected on a larger scale, along a wider transect covering both the eastern and western Mediterranean Sea, making the interpretation of bacteria distribution data across the water column more difficult. The absence of a sharp profiling of bacterial communities according to depth in the intermediate layers of the water column could possibly be influenced by the extremely hydrographically complex nature of the system, where several water masses at different spatial and temporal scales concur with the water composition of meso- and bathypelagic layers (Gačić et al., 2010; Rubino et al., 2012).
The observed spatial pattern of bacterial communities throughout the water column was related to different variables, specifically the site of sampling (longitude), the depth of collection (pressure) and the water salinity and temperature values. Our results regarding bacterial stratification across the water column are in agreement with previous studies carried out in the Mediterranean Sea and different oceanic regions (De Corte et al., 2009; DeLong et al., 2006; Winter et al., 2008). Further studies are necessary to correlate bacterial zonation according to water mass composition, particularly in light of the high variability of bacterial microbiome composition in samples characterized by the same T-S values in the eastern Mediterranean Sea (Yokokawa et al., 2010). These findings are consistent with the notion that physical conditions of deep ocean environments are more stable than those at the ocean surface, while concentration and composition of organic constituents could display relatively high variability (Nagata et al., 2010, and references therein).

\section{Conclusions}

Our study provides a comprehensive depiction of bacterioplankton community structure across the water column over a longitudinal transect covering the whole Mediterranean Sea. As recently emerged from the study of specific bacterial taxa (Feingersch et al., 2010; Lamy et al., 2011; Mella-Floreset al., 2011), our investigation demonstrated that the overall planktonic bacterial community inhabiting epipelagic seawater was also spatially patterned in the Mediterranean Sea, exhibiting different populations in the eastern and western basins. The bacterial community distribution shifted along the epi-, upper and lower mesoand bathypelagic zones of the Mediterranean Sea according to spatial and physico-chemical parameters including longitude, pressure, temperature and salinity. Bacterial zonation according to depth was also demonstrated. Partial evidence was provided, concerning the relationship between bacterial community structure and water masses in the different water column layers. Due to the distribution patchiness of the intermediate levels of the water column and the interleaving phenomena of water masses (Rubino et al., 2012), the hypothesis of a correlation between communities and water masses should be confirmed by large-scale studies of the whole Mediterranean Sea. Global warming is estimated to have an impact on oceanic circulation and on the entrance of exotic species into the Mediterranean Sea. These factors are putatively involved in shifts of the biogeochemical cycles, which are triggered by microbial activity. Therefore, a deeper knowledge of the mechanisms driving bacterial diversity in the whole Mediterranean basin may be crucial in view of climate change.

\section{Supplementary material related to this article is available online at: http://www.ocean-sci.net/9/585/2013/ os-9-585-2013-supplement.zip.}


Acknowledgements. We gratefully thank the master and crew of the R/V Meteor for excellent technical assistance. Special thanks to V. Hernando-Morales and E. Teira for help with the ARISA fingerprinting and to Giuseppe Civitarese for nutrient analyses. The authors wish to thank the anonymous reviewers for their constructive comments. F. Mapelli was supported by Università degli Studi di Milano, European Social Fund (FSE) and Regione Lombardia (contract "Dote Ricerca"). R. Alvariño was supported by a Master Scholarship by the "Campus do Mar". The work has been partially supported by the European Community FP7-KBBE-2010-4 project ULIXES grant agreement N. 266473 and the project "Transecto" en el Mar Mediterráneo: del 2001 al 2011, MED-SEA-REPEAT (Ref. CTM2010-12244-E) funded by the Spanish National I+D Plan.

Edited by: N. Kress

\section{References}

Agogué, H., Lamy, D., Neal, P. R., Sogin, M. L., and Herndl, G. J.: Water mass-specificity of bacterial communities in the North Atlantic revealed by massively parallel sequencing, Mol. Ecol., 20, 258-274, 2011.

Anderson, M. J.: A new method for non-parametric multivariate analysis of variance, Austral. Ecol., 26, 32-46, 2001.

Anderson, M. J.: DISTLM v.2: a FORTRAN computer program to calculate a distance-based multivariate analysis for a linear model, Department of Statistics, University of Auckland, 2002.

Anderson, M. J., Gorley, R. N., and Clarke, K. R.: PERMANOVA+ for PRIMER: Guide to Software and Statistical Methods, PRIMER-E, Plymouth, UK, 2008.

Arístegui, J., Gasol, J. M., Duarte, C. M., and Herndl, G. J.: Microbial Ocenography of the dark ocean's pelagic realm, Limnol. Ocenogr., 54, 1501-1529, 2009.

Bensi, M., Rubino, A., Cardin, V. R., Hainbucher, D., and ManceroMosquera, I.: Structure and variability of the abyssal water masses in the Ionian Sea in the period 2003-2010, J. Geophys. Res., 118, 931-943, doi:10.1029/2012JC008178, 2013

Borin, S., Brusetti, L., Daffonchio, D., Delaney, E., and Baldi, F.: Biodiversity of prokaryotic communities in sediments of different sub-basins of the Venice lagoon, Res. Microbiol., 5, 307-314, 2009a.

Borin, S., Brusetti, L., Mapelli, F., D’Auria, G., Brusa, T., Marzorati, M., Rizzi, A., Yakimov, M., Marty, D., De Lange G. J., Van der Wielen, P., Bolhuis, H., McGenityh, T. J., Polymenakoui, P. N., Malinverno, E., Giuliano, L., Corselli, C., and Daffonchio, D.: Sulfur cyclingandmethanogenesisprimarilydrivemicrobialcolonizationofthehighlysulfidic Urania deephypersalinebasin, P. Natl. Acad. Sci USA, 106, 9151-9156, 2009 b.

Brown, M. V., Schwalbach, M. S., Hewson, I., and Fuhrman, J. A.: Coupling 16S-ITS rDNA clone libraries and automated ribosomal intergenic spacer analysis to show marine microbial diversity: development and application to a time series, Environ. Microbiol. 7, 1466-1479, 2005.

Cardinale, M., Brusetti, L., Quatrini, P., Borin, S., Puglia, A. M., Rizzi, A., Zanardini, E., Sorlini, C., Corselli, C., and Daffonchio, D.: Comparison of different primer sets for use in automated ribosomal intergenic spacer analysis of complex bacterial communities, Appl. Environ. Microb., 70, 6147-6156, 2004.
Clarke, K. and R. Gorley: "PRIMER v6.” User manual/tutorial. Plymouth routine in mulitvariate ecological research, Plymouth Marine Laboratory, 2006.

Coll, M., Piroddi, C., Steenbeek, J., Kaschner, K., Ben RaisLasram, F., Aguzzi, J., Ballesteros, E., Bianchi, C. N., Corbera, J., Dailianis, T., Danovaro, R., Estrada, M., Froglia, C., Gali, B. S., Gasol, J. M., Gertwagen, R., Gil, J., Guilhaumon, F., Kesner-Reyes, K., Kitsos, M. S., Koukouras, A., Lampadariou, N., Laxamana, E., López-Fé de la Cuadra, C. M., Lotze, H. K., Martin, D., Mouillot, D., Oro, D., Raicevich, S., Rius-Barile, J., Saiz-Salinas, J. I., San Vicente, C., Somot, S., Templado, J., Turon, X., Vafidis, D., Villanueva, R., and Voultsiadou, E.: The Biodiversity of the Mediterranean Sea: Estimates, Patterns, and Threats, Plos One, 5, 1-36, 2010.

De Corte, D., Yokokawa, T., Varela, M. M., Agogué, H., and Herndl, G. J.: Spatial distribution of Bacteria and Archaea and amoA gene copy numbers throughout the water column of the Eastern Mediterranean Sea, ISME J., 3, 147-158, 2009.

DeLong, E. F., Preston, C. M., Mincer,T., Rich, V., Hallam, S. J., Frigaard, N., Martinez, A., Sullivan, M. B., Edwards, R., Rodriguez Brito, B., Chisholm,S. W., and Karl, D. M.: Community Genomics Among Stratified Microbial Assemblages in the Ocean's Interior, Science, 311, 496-503, 2006.

Fegatella, F., Lim, J., Kjelleberg, S., and Cavicchioli, R.: Implications of rRNA operon copy number and ribosome content in the marine oligotrophic ultramicrobacteriumSphingomonas sp. strain RB2256, Appl. Environ. Microb., 64, 4433-4438, 1998.

Feingersch, R., Suzuki M. T., Shmoish, M., Sharon, I., Sabehi, G., Partensky, F., and Béjà, O.: Microbial community genomics in eastern Mediterranean Sea surface waters, ISME J., 4, 78-87, 2010.

Fuhrman J. A., Steele, J. A., Hewson, I., Schwalbach, M. S., Brown, M. V., Green, J. L., Brown, J. H.: A latitudinal diversity gradient in planktonic marine bacteria, P. Natl. Acad. Sci. USA, 105, 7774-7778, 2008.

Gačić, M., EusebiBorzelli, G. L., Civitarese, G., Cardin, V., and Yari, S.: Can internal processes sustain reversals of the ocean upper circulation? The Ionian Sea example, Geophys. Res. Lett., 37, L09608, doi:10.1029/2010GL043216, 2010.

Galand, P. E., Lovejoy, C., Hamilton, A. K., Ingram, R. G., Pedneault E., and Carmack, E. C.: Archaeal diversity and a gene for ammonia oxidation are coupled to oceanic circulation, Environ. Microbiol., 11, 971-980, 2009.

Hamilton, A. K., Lovejoy, C., Galand, P. E., and Ingram, R. G.: Water masses and biogeography of picoeukaryote assemblages in a cold hydrographically complex system, Limnol. Oceanogr., 53, 922-935, 2008.

Hecht, A., Pinardi, N., and Robinson, A. R.: Currents, water masses, eddies and jets in the mediterraneanlevantine basin, J. Phys. Oceanogr., 18, 1320-1353, 1988.

Hewson, I., Steele, J. A., Capone, D. G., and Fuhrman, J. A.: Temporal and spatial scales of variation in bacterioplankton assemblages of oligotrophic surface waters, Mar. Ecol.-Prog. Ser., 311, 67-77, 2006.

Lamy, D., Jeanthon, C., Cottrell, M. T., Kirchman, D. L., Van Wambeke, F., Ras, J., Dahan, O., Pujo-Pay, M., Oriol, L., Bariat, L., Catala, P., Cornet-Barthaux, V., and Lebaron, P.: Ecology of aerobic anoxygenic phototrophic bacteria along an oligotrophic gradient in the Mediterranean Sea, Biogeosciences, 8, 973-985, 
doi:10.5194/bg-8-973-2011, 2011.

Li, W. K. W., McLaughlin, F. A., Lovejoy, C., and Carmack, E. C.: Smallest algae thrive as the Arctic Ocean freshens, Science, 326, p. 539, 2009.

Lovejoy, C., Carmack, E. C., Legendre, L., and Price, N. M.: Water column interleaving: a new physical mechanism determining protist communities and bacterial states, Limnol. Oceanogr., 47, 1819-1831, 2002.

Luna, G. M., Binachelli, S., Decembrini, F., De Domenico, E., Danovaro, R., and Dell'Anno, A.: The dark portion of the Mediterranean Sea is a bioreactorof organic matter cycling, Global Biogeochem. Cy., 26, GB2017, doi:10.1029/2011GB004168, 2012.

Mella-Flores, D., Mazard, S., Humily, F., Partensky, F., Mahé, F., Bariat, L., Courties, C., Marie, D., Ras, J., Mauriac, R., Jeanthon, C., Mahdi Bendif, E., Ostrowski, M., Scanlan, D. J., and Garczarek, L.: Is the distribution of Prochlorococcus and Synechococcus ecotypesin the Mediterranean Sea affected by global warming?, Biogeosciences, 8, 2785-2804, doi:10.5194/bg-82785-2011, 2011.

Moeseneder, M. M., Winter, C., and Herndl G. J.: Horizontal and vertical complexity of attached and free-living bacteria of the eastern Mediterranean Sea, determined by $16 \mathrm{~S}$ rDNA and $16 \mathrm{~S}$ rRNA fingerprints, Limnol. Oceanogr., 46, 95-107, 2001.

Nagata, T., Tamburini, C., Arístegui, J., Baltar, F., Bochdansky, A. B., Fonda-Umani, S., Fukuda, H., Gogou, A., Hansell, D. A., Hansman, R. L., Herndl, G. J., Panagiotopoulos, C., Reinthaler, T., Sohrin, Rumi, S., Verdugo, P. Yamada, N., Yamashita, Y., Yokokawa, T., and Barlett, D. H.: Emerging concepts on microbial processes in the bathypelagic ocean - ecology, biogeochemistry, and genomic, Deep-Sea Res. Pt. II, 57, 1519-1536, 2010.

Pinardi, N. and Masetti, E.: Variability of the large scale general circulation of the Mediterranean Sea from observations and modelling: a review, Palaeogeogr. Palaeocl., 158, 153-173, 2000.

Rahav, E., Herut, B., Levi, A., Mulholland, M. R., and BermanFrank, I.: Springtime contribution of dinitrogenfixation to primary production across theMediterranean Sea, Ocean Sci. Discuss., in preparation, 2013.

Rubino, A. and Hainbucher, D.: A large abrupt change in the abyssal water masses of the eastern Mediterranean, Geophys. Res. Lett., 34, L23607, doi:10.1029/2007GL031737, 2007.

Rubino, A., Falcini, F., Zanchettin, D., Bouche, V., Salusti, E., Bensi, M., Riccobene, G., De Bonis, G., Masullo, R., Simeone, F., Piattelli, P., Sapienza, P., Russo, S., Platania, G., Sedita, M., Reina, P., Avolio, R., Randazzo, N., Hainbucher, D., and Capone, A.: Abyssalundularvortices in the EasternMediterraneanbasin, Nature Comm., 3, 834, doi:10.1038/ncomms1836, 2012.

Tamburini, C., Garel, M., Al Ali, B., Mérigot, B., Kriwy, P., Charrière , B., and Budillon, G.: Distribution and activity of Bacteria and Archaea in the different water masses of the Tyrrhenian Sea, Deep-Sea Res. Pt. II, 56, 700-712, 2009.
Tanhua, T., Hainbucher, D., Cardin, V., Álvarez, M., and Civitarese, G.: Repeat hydrography in the Mediterranean Sea, data from the Meteor cruise 84/3 in 2011, Earth Syst. Sci. Data Discuss., 6, 59-71, doi:10.5194/essdd-6-59-2013, 2013a.

Tanhua, T., Hainbucher, D., Schr”oder, K., Cardin, V., Álvarez, M., and Civitarese, G.: The Mediterranean Sea system: a review and an introduction to the special issue, Ocean Sci. Discuss., 10, 581617, doi:10.5194/osd-10-581-2013, 2013 b.

Thingstad, T. F., Krom, M. D., Mantoura, R. F. C., Flaten, G. A. F., Groom, S., Herut, B., Kress, N., Law, C. S., Pasternak, A., Pitta, P., Psarra, S., Rassoulzadegan, F., Tanaka, T., Tselepides, A., Wassmann, P., Woodward, E. M. S., Wexels Riser, C., Zodiatis, G., and Zohary, T.: Nature of phosphorus limitation in the ultraoligotrophic Eastern Mediterranean, Science, 309, 1068-1071, 2005.

Varela, M. M., van Aken, H. M., Sintes, E., and Herndl, G. J.: Latitudinal trends of Crenarchaeota and Bacteria in the meso- and bathypelagic water masses of the Eastern North Atlantic, Environ. Microbiol., 10, 110-124, 2008a.

Varela, M. M., van Aken, H. M., and Herndl, G. J.: Abundance and activity of Chloroflexy-type SAR202 bacterioplankton in the meso- and bathypelagic waters of the (sub) tropical Atlantic, Environ. Microbiol., 10, 1903-1911, 2008b.

Winter, C., Moeseneder, M. M., Herndl, G. J., and Weinbauer, M. G.: Relationship of Geographic Distance, Depth, Temperature, and Viruses with Prokaryotic Communities in the Eastern Tropical Atlantic Ocean, Microb. Ecol., 56, 383-389, 2008.

Winter, C., Kerros, M.-E., and Weinbauer, M. G.: Seasonal changes of bacterial and archaeal communities in the dark ocean: evidence from the Mediterranean Sea, Limnol. Ocenogr., 54, 160 170, 2009.

Yilmaz, P., Iversen, M. H., Hankeln, W., Kottmann, R., Quast, C., and Glöckner, F. O.: Ecological structuring of bacterial and archaeal taxa in surface ocean waters, FEMS Microbiol. Ecol., 8, 373-385, 2012.

Yokokawa, T., De Corte, D., Sintes, E., and Herndl, G. J.: Spatial patterns of bacterial abundance, activity and community composition in relation to water masses in the eastern Mediterranean Sea, Aquat. Microb. Ecol., 59, 185-195, 2010.

Zaccone, R., Boldrin, A., Caruso, G., La Ferla, R., Maimone, G., Santinelli, C., and Turchetto, M.: Enzymatic Activities and Prokaryotic Abundance in Relationto Organic Matter along a West-East MediterraneanTransect (TRANSMED Cruise), Microb. Ecol., 64, 54-66, 2012.

Zehr, J. P., Hewson, I., and Moisander, P.: Molecular biology techniques and applications for ocean sensing, Ocean Sci., 5, 101113, doi:10.5194/os-5-101-2009, 2009. 